International Business and Global Economy 2019, no. 38, pp. 119-137

Biznes międzynarodowy w gospodarce globalnej 2019, nr 38, s. 119-137

Edited by the Institute of International Business, University of Gdańsk

ISSN 2300-6102

e-ISSN 2353-9496

DOI 10.4467/23539496IB.19.007.11506

\author{
Zdzisław W. Puślecki \\ Uniwersytet im. Adama Mickiewicza w Poznaniu
}

\title{
Unia Europejska a Nowy Jedwabny Szlak
}

Głównym celem artykułu jest przedstawienie stanowiska Unii Europejskiej wobec Nowego Jedwabnego Szlaku jako nowego chińskiego projektu skierowanego zarówno do państw rozwiniętych, jak i rozwijających się, który ma poszerzyć powiązania ekonomiczne w skali globalnej. Główną metodą badawczą zastosowaną w opracowaniu była metoda naukowa, w tym instytucjonalna, komparatywna, dokumentacyjna i statystyczna. Dodatkowo zastosowano także metodę dedukcyjną i metodę przewidywania indukcyjnego. Podjęte badania wskazują, że w Unii Europejskiej, m.in. w Niemczech, intensywnie rozmyśla się nad reakcją na chińskie plany inwestycyjne. Zauważa się, iż „Nowy Jedwabny Szlak” nie jest, jak sądzą niektórzy, jedynie sentymentalnym wspomnieniem, a próbą stworzenia ogromnego systemu, za pomocą którego Chińczycy chcą wycisnąć swoje piętno w świecie. Państwa Unii Europejskiej obawiają się, że celem tego nowego projektu jest przede wszystkim wzmocnienie oddziaływania Chin na gospodarkę światową i dążenie do zaspokojenia wyłącznie własnych interesów. We wnioskach wskazuje się, że w zależności od tego, jakie reguły będą obowiązywać w powyższym projekcie, będzie to albo współpraca, albo hegemonia.

Słowa kluczowe: Unia Europejska, Chiny, Nowy Jedwabny Szlak, rozwój ekonomiczny, geopolityczna kalkulacja

Klasyfikacja JEL: F63

\section{European Union and New Silk Road}

The main aim of the article is to present the European Union's position on the New Silk Road (One Belt One Road-OBOR, or 'Belt and Road Initiative' - BRI) understood as a project launched by China and directed at both developed and developing countries in order to broaden its economic connections. The main method applied in this research was the scientific method, including institutional, comparative, documentation, and statistical methods. Additionally, the methods of deductive and inductive forecasting were also used. The research indicates that in the European Union, i.a. Germany, there is much deliberation about the reaction to the Chinese investment plans. It has been noted that the 'New Silk Road' is not, as some seem to think, merely a sentimental memory, but an attempt to create an enormous system through which China wants to make its mark in the world. The Member States of the European Union fear that the aim of the new project is first and foremost to strengthen China's influence on the global economy and its pursuit of satisfying only its own interests. It has been concluded that depending on the principles governing the project it will be either a cooperation, or a hegemony.

Keywords: European Union, China, New Silk Road, economic development, geopolitical calculation JEL classification: F63 


\section{Wprowadzenie}

W długofalowej strategii rozwoju Chin (Chińska Republika Ludowa - ChRL) zauważalne jest kopiowanie modelu zarządzania krajem wprowadzonego wiele lat temu w Singapurze. Kraj ten najpierw był kolonią brytyjską, a następnie ustanowiono tam (z perspektywy Zachodu) dyktaturę. Podkreślić należy, że sam model singapurski sprawdza się znakomicie. Na poziomie makro mamy w Singapurze do czynienia z jednym i tym samym rządem od ponad 30 lat, z kolei na poziomie mikro wprowadzona została bardzo szeroko pojęta wolność gospodarcza. Połączenie stabilności politycznej oraz wolności gospodarczej daje efekty w postaci szybkiego rozwoju kraju.

Chiny ewidentnie starają się przenieść powyższy model na własne terytorium. Co ważne, aż $80 \%$ kadry rządzącej w Chinach to osoby z wykształceniem technicznym. Państwo Środka zarządzane jest zatem przede wszystkim przez ludzi wdrażających nowe technologie, automatyzujące kraj. W ten sposób tworzy się fundamenty pod długofalowy rozwój. Celem artykułu jest przedstawienie stanowiska Unii Europejskiej wobec chińskiego projektu Nowego Jedwabnego Szlaku.

\section{Sytuacja na Morzu Południowochińskim}

Obawy przedstawicieli kół rządowych w Chinach o utrzymanie własnego terytorium związane są obecnie przede wszystkim z sytuacją na Morzu Południowochińskim. Kontrola tego obszaru zapewnia Państwu Środka przepływ towarów, co ma kluczowe znaczenie dla rozwoju gospodarczego. Utrzymanie obecnej sytuacji w tym regionie jest dla Chin niezwykle ważnym priorytetem.

Tymczasem dużą aktywność na tym właśnie obszarze wykazują również Stany Zjednoczone. W ostatnich latach USA miały swój udział w poszerzaniu potencjału militarnego m.in. Korei Południowej, Tajwanu, a także Filipin. Z perspektywy Chin takie działania muszą być odczuwalne. Wystarczy podać przykład: USA sprzedają broń Tajwanowi, a przecież Chiny są jednym z głównych wierzycieli Stanów Zjednoczonych. Można powiedzieć, że w ten sposób Chiny pośrednio biorą udział w uzbrajaniu Tajwanu przeciwko samym sobie.

W takiej sytuacji Chiny nie wykazują większej inicjatywy, aby pomagać USA podczas napięć z Koreą Północną. Kolejnym ważnym elementem rozgrywki na Morzu Południowochińskim jest zainstalowanie przez USA na terenie Korei Południowej systemu THAAD, umożliwiającego przechwytywanie i niszczenie pocisków balistycznych. O ile samo wzmocnienie Korei Południowej przez USA nie stanowiłoby tak dużego problemu, o tyle spore komplikacje dla Chin powo- 
duje zainstalowany równocześnie system radarowy - sięga on daleko w głąb Państwa Środka i obejmuje również część Rosji.

Kolejnym punktem zapalnym są żądania Filipin, które zaskarżyły Chiny do Trybunału w Hadze, twierdząc, że władze chińskie bezpodstawnie przyznały sobie prawo do kontrolowania części wysp. Trybunał przyznał filipińskim władzom rację. W odpowiedzi Chiny oświadczyły, że nie zamierzają respektować wyroku. Nie było to oczywiście żadne zaskoczenie - ostatecznie jeżeli Chiny oddadzą kontrolę nad częścią wysp Filipinom lub Wietnamowi (sojusznikom USA), handel morski może zostać zablokowany.

Ponadto należy zauważyć, że pod Morzem Południowochińskim znajdują się znaczne złoża ropy naftowej i gazu. Można sobie zatem wyobrazić, że Chiny w czasie rozmów z Filipinami dzielą się wpływami z surowców. Trudno jednak oczekiwać, że Państwo Środka mogłoby zrezygnować z militarnej kontroli nad tym regionem. Stawką jest kontrola nad szlakami morskimi, mogłoby pojawić się jednak pytanie, czy rzeczywiście są one aż tak ważne. W odpowiedzi należy wskazać, że dla Chin, owszem, są bardzo ważne. Są to także najbardziej zatłoczone trasy na świecie, a wraz z rozwojem Chin handel będzie się jedynie nasilał. To właśnie w tym regionie przepływa 50\% statków transportujących ropę naftową. Na samych terenach przylegających do szlaków mieszka około $100 \mathrm{mln}$ ludzi. Nie ulega zatem wątpliwości, że jest o co walczyć.

Należy podkreślić, że Chiny w ciągu kilku dekad dokonały niewiarygodnego skoku cywilizacyjnego. Aby jednak móc korzystać ze swoich dokonań, Państwo Środka musi utrzymać kontrolę nad Morzem Południowochińskim. Właśnie dlatego tak wielki niepokój budzą działania USA oraz gęsta siatka amerykańskich baz i instalacji wojskowych rozmieszczonych w pobliżu Chin.

\section{Interesy chińskie}

Przystępując do rozważań wynikających z otwarcia Nowego Jedwabnego Szlaku, należy podkreślić, że poprzez rozwój przede wszystkim infrastruktury działania te istotnie wpłyną na zabezpieczanie interesów chińskich we współczesnym świecie. Inicjatywa Nowego Jedwabnego Szlaku (Belt and Road Initiative - BRI) jest zupełnie nową marką. Od momentu pojawienia się cztery lata temu uzyskała poparcie ponad 100 krajów i organizacji międzynarodowych, z których ponad 80 podpisało umowy z Chinami. Warto zaznaczyć, że Europa i Chiny są przy tym projekcie naturalnymi partnerami ze względu na położenie. Dzięki wspólnym wysiłkom obydwu stron strategia Europy i BRI tworzą też swoistą synergię.

Należy tu zwrócić uwagę na wzrost liczby połączeń towarowych między Chinami a Europą. W 2017 r. zrealizowano 3673 połączeń, co w porównaniu z 2016 r. 
oznacza wzrost o 116\%. Usługi kolejowe są realizowane do 36 miast europejskich w 13 państwach, co znacznie ułatwia dostęp do towarów europejskich, w tym polskich, na rynku chińskim.

Według chińskich przedstawicieli Nowy Jedwabny Szlak można opisać trzema słowami: otwartość, przejrzystość i inkluzywność. Podkreśla się równocześnie, że celem inicjatywy jest promowanie współpracy gospodarczej poprzez połączenia infrastrukturalne i doprowadzenie do wspólnego rozwoju drogą wykorzystania porównywalnych mocnych stron jej wszystkich uczestników.

Dążąc do zapewnienia sobie integralności terytorialnej, ale również myśląc o dalszej ekspansji, Chiny postanowiły samodzielnie odbudowywać Nowy Jedwabny Szlak. Wyszły równocześnie z ofertą rozwoju infrastruktury, w tym wybudowania autostrad czy mostów. W zamian oczekują otwarcia się danego kraju na wymianę handlową z Państwem Środka. Zdarza się jednak, że Chińczycy wykorzystują również bardziej wyrafinowane metody.

Przechodząc do kwestii samego Jedwabnego Szlaku w nowej odsłonie, warto zwrócić uwagę na jego planowane i już utworzone elementy. Władze ChRL widzą w projekcie Nowego Jedwabnego Szlaku sposób na rozwój ekonomiczny prowincji położonych w głębi kraju i lepsze skomunikowanie ich z wybrzeżem oraz stolicą. W kontekście gospodarczo-politycznym chodzi również o rozwój eksportu do odciętych od morza krajów Azji Środkowej oraz położonych w głębi lądu regionów państw ościennych bezpośrednio sąsiadujących z Chinami. Trzeci powód ma charakter zdecydowanie geopolityczny i jest związany z tzw. dylematem Malakki. Większość morskiego handlu Chin, w tym $80 \%$ importu ropy naftowej, przechodzi przez Cieśninę Malakka, gdzie najważniejszym portem jest sprzymierzony z USA Singapur. Nawet częściowe ograniczenie tej niebezpiecznej sytuacji dzięki korytarzom ekonomicznym przez Pakistan i Birmę jest dla Pekinu warte każdych pieniędzy. Co ciekawe, ostatnie projekty w ramach Morskiego Jedwabnego Szlaku również koncentrują się wokół cieśniny Malakka, gdzie Chińczycy najwyraźniej starają się stworzyć konkurencję dla Singapuru. Najważniejszym projektem jest tutaj Melaka Gateway w Malezji. Wobec braku widocznych rezultatów inicjatywy przekopania kanału przez przesmyk Kra w Tajlandii pozwalającego ominąć Malakkę w Pekinie mogła zapaść decyzja o budowie własnych portów w tym strategicznie ważnym regionie.

Na drugim końcu Morskiego Jedwabnego Szlaku o rolę hubu morskiego zabiega Wenecja. Włosi chcą tym sposobem przywrócić miastu dawną świetność i podjąć rywalizację z wielkimi portami północnej Europy: Rotterdamem i Hamburgiem. Plan jest bardzo ambitny i zakłada utworzenie przy pomocy programu Trans-European Transport Networks (TEN-T) olbrzymiego kompleksu portowego złożonego z Wenecji, Rawenny, Triestu i słoweńskiego Kopru, który zapewniałby przeładunek towarów kierowanych następnie do Włoch, Szwajcarii, Austrii, Nie- 
miec, a także na Węgry i zachodnie Bałkany. Projekt zyskał już zainteresowanie strony chińskiej.

Warto zaznaczyć, że pozornie wszystko wydaje się odbywać zgodnie z wielokrotnymi zapewnieniami Xi Jinpinga - Inicjatywa Pasa i Szlaku to szansa na rozwój i bogactwo dla wszystkich, a Jedwabny Szlak to program czysto gospodarczy. Przypadek Hambantoty na Sri Lance sugeruje jednak coś innego. Szacowane na 1-1,3 mld USD inwestycje miały w 2017 r. przykry finał dla rządu w Kolombo. Początkowe ustalenia mówiły o równym podziale udziałów pomiędzy władze wyspy a chińskie państwowe przedsiębiorstwo China Merchants Port Holdings (CMPH). Jednak w 2016 r., po niejawnych i niejasnych negocjacjach, lankijski rząd zgodził się, aby CMPH kontrolował aż $80 \%$ udziałów w porcie. Wywołało to protesty opozycji i związków zawodowych, które zmusiły rząd do renegocjacji umowy. Wówczas do sprawy włączyły się władze chińskie. Wykorzystując zadłużenie wyspiarskiego państwa, Chiny wymusiły przekazanie CMPH 70\% udziałów. Transakcję zaliczono na poczet spłaty długów. Zawarta w lipcu 2017 r. umowa była dopiero początkiem. Przyparte do muru Kolombo w grudniu 2017 r. zgodziło się na wydzierżawienie CMPH portu i specjalnej strefy ekonomicznej w Hambantocie na okres 99 lat. Niejako na pociechę umowa zakłada, że port nie będzie wykorzystywany przez chińską marynarkę wojenną. Wydaje się to jednak wątpliwe, zważywszy, że już w 2014 r. do Hambantoty zawinął, bez oglądania się na władze portowe, chiński okręt podwodny.

Pojawia się pytanie, jak duże były długi Sri Lanki wobec Chin, że umożliwiły władzom chińskim tak zdecydowane postawienie sprawy. Okazuje się, że dzierżawę Hambantoty potraktowano jako spłatę 1 mld USD. Kwota ta stanowiła raptem ok. 12\% całości długów zagranicznych Sri Lanki. Szacuje się jednak, że wskutek projektów związanych z Nowym Jedwabnym Szlakiem wartość ta może wzrosnąć do 17\%. W dużo gorszej sytuacji znalazły się Malediwy. Wyspiarskie państwo znalazło się w kryzysie po tym, jak sąd najwyższy nakazał prezydentowi Abdulli Yameenowi zwolnić z więzienia członków opozycji. Prezydent nie ustąpił i wprowadził stan wyjątkowy. Sytuacja na Malediwach stała się do tego stopnia napięta, że Indie zaczęły rozważać interwencję militarną.

Do takiej złożonej sytuacji włączyły się władze chińskie, ostrzegając New Delhi, że każda jednostronna akcja Indii spotka się z reakcją Chin. Niejako na potwierdzenie tych słów na Oceanie Indyjskim przebywał zespół chińskiej marynarki wojennej złożony przynajmniej z jednego niszczyciela, fregaty, okrętu desantowego i jednostki zaopatrzeniowej. W cieniu kryzysu władze Malediwów zawarły z Chinami transakcję: w ramach spłaty części długów wydzierżawiły dwie niezamieszkane wysepki. Władze chińskie już wcześniej wykazywały zainteresowanie pozyskaniem którejś z niezamieszkanych wysp archipelagu i zbudowaniem tam bazy marynarki wojennej, a także wycięciem fragmentów rafy 
koralowej, aby stworzyć odpowiednie przejścia dla okrętów. Realizacja tych planów coraz bardziej się przybliża, a wszystko dzięki zaledwie 1,5-2 mld USD długów - co jednak stanowi aż 80\% zadłużenia zagranicznego Malediwów. Ekonomiści już zaczęli mówić, że Chiny w ramach Inicjatywy Pasa i Szlaku przygotowują pułapki debetowe na biedniejsze państwa w celu maksymalizacji własnych zysków oraz realizacji celów politycznych. Przykładowo w Gwadarze zaledwie 9\% zysków z portu trafia do władz Pakistanu, a reszta przekazywana jest do Chin.

Należy zaznaczyć, że chińskie pożyczki są wprawdzie łatwiej dostępne niż fundusze międzynarodowych instytucji i państw zachodnich, jednakże ich oprocentowanie wynosi nawet 7\%. Sri Lanka i Malediwy to dopiero początek - wśród innych narażonych państw wymienia się Bangladesz, Birmę, Nepal i Pakistan. Lista ta, którą poszerza się także o Laos, Mongolię, Kirgistan, Tadżykistan, Dżibuti i Czarnogórę, tworzy spójną całość. Laos zapewnia przyczółek w Indochinach, bezpośrednie połączenie lądowe z Kambodżą i okrążenie Wietnamu od zachodu. Tadżykistan i Kirgistan tworzą podobny przyczółek w Azji Środkowej i podminowują wpływy Rosji w regionie. Nepal, Bangladesz, Sri Lanka i Malediwy są wyrywane z indyjskiej strefy wpływów, a wraz z Birmą i Pakistanem tworzą chiński pierścień wokół Indii. Dżibuti jest kolejnym elementem tej strategii, zapewniającym bazę $\mathrm{w}$ strategicznie ważnym punkcie na szlaku morskim prowadzącym do Europy, w tym do Czarnogóry. Ten ostatni kraj to przyczółek na Bałkanach. Z kolei na terenie Mongolii, postrzeganej jako naturalna strefa wpływów Chin, znajdują się złoża surowców, tamtędy też prowadzą szlaki w głąb wschodniej Syberii. Kiedy mówi się o pułapce debetowej, natychmiast nasuwa się pytanie o Stany Zjednoczone. Okazuje się, że sytuacja nie jest taka zła, jak mogłoby się wydawać. Chiny są wprawdzie największym zagranicznym wierzycielem USA, ale tylko nieznacznie wyprzedzają Japonię. Ogólnie tylko 18\% amerykańskiego długu publicznego to zobowiązania wobec podmiotów zewnętrznych.

Przypadki wspomnianych powyżej państw, asertywna polityka zewnętrzna i wykorzystywanie inwestycji w celach politycznych pokazują, że chińskie przywództwo dobrze odrobiło lekcję "stulecia upokorzeń". Historiografia chińska określa tym terminem lata 1839-1949, kiedy Państwo Środka padło ofiarą ekspansji zachodnich mocarstw. Państwowa propaganda bardzo chętnie wykorzystuje ten motyw, propagując w społeczeństwie poczucie krzywdy i prezentując Komunistyczną Partię Chin (KPCh) jako egzekutora "sprawiedliwości dziejowej”, przywracającego Chinom należne im miejsce $\mathrm{w}$ świecie. Jednym $\mathrm{z}$ narzędzi do realizacji tego celu jest Inicjatywa Pasa i Szlaku. Jest to przekaz łagodny, na użytek zewnętrzny. $\mathrm{W}$ taką retorykę wpisuje się również wystąpienie Xi Jinpinga na XIX kongresie KPCh w październiku 2017 r., gdzie otwarcie stwierdził on, że głównym celem partii jest uczynienie Chin światowym numerem jeden do $2049 \mathrm{r}$. Jest to otwarte wyzwanie rzucone dominacji USA i, ogólnie, świata zachodniego. 
Chiny starają się, póki co z umiarkowanym skutkiem, tworzyć alternatywne międzynarodowe struktury gospodarcze, finansowe oraz nową rzeczywistość w prawie międzynarodowym.

Pojawia się tu specyfika chińskiego podejścia do stosunków międzynarodowych. ChRL to obecnie jedyne mocarstwo nieposiadające i niezabiegające o rzeczywistych sojuszników, co dotyczy również Rosji. Jest to efekt doświadczeń historycznych. Chiny aż do XIX w. nie musiały z nikim rywalizować, wchodzić w sojusze, tworzyć lub odpierać koalicji, były samowystarczalnym światem samym w sobie. Wszystkie inne pobliskie państwa były dużo słabsze i nie stwarzały zagrożenia. Jedyna groźba pochodziła ze strony Wielkiego Stepu. Wojowniczy nomadowie wielokrotnie podbijali północną część, a niekiedy całość Chin. Za każdym razem jednak powtarzał się ten sam scenariusz - nieliczni zdobywcy w ciągu 2-3 pokoleń ulegali sinizacji i za wszelką cenę starali się udowodnić, że są bardziej chińscy od Hanów (głównej chińskiej grupy etnicznej). Zaowocowało to niewzruszonym przekonaniem o wyższości chińskiej cywilizacji oraz specyficznym podejściem do stosunków międzynarodowych, tzw. systemem trybutarnym. Z racji braku równorzędnych partnerów inne państwa mogły być jedynie podporządkowane Państwu Środka. Tak długo jak „barbarzyńscy” władcy uiszczali roczny trybut, otrzymywali prawo do handlu z Chinami oraz podarunki od cesarza, których wartość była najczęściej większa od składanych danin. W sprawy trybutariuszy ingerowano niezwykle rzadko.

Od tej reguły były trzy istotne wyjątki. Za każdym razem, gdy do władzy dochodziła silna dynastia kontrolująca całość rdzennego chińskiego terytorium, do głosu dochodziła geopolityka. Powodowało to regularne i najczęściej skuteczne próby podporządkowania Korei oraz północnej części Wietnamu, a także stałe zaangażowanie w Azji Środkowej. To wyzwanie było niezwykle istotne. Celem chińskiej polityki było zapobieżenie wyłonieniu się wśród nomadów potęgi zdolnej zagrozić Państwu Środka. W drugiej połowie XVII w. rolę takiego niebezpieczeństwa przejęła Rosja i utrzymała ją aż do rozpadu ZSRR. Wówczas uwolnione od stałego zagrożenia z głębi lądu Chiny mogły zwrócić wzrok w innych kierunkach i zacząć przeistaczać się z mocarstwa lądowego w potęgę lądową i morską [Behrendt, 2018].

Bardzo istotny jest fakt, że szlak będzie obejmował kraje, które w kolejnych 10 latach mają przodować pod względem wzrostu PKB. Z drugiej strony najlepsze prognozy dotyczą Indii (przewidywany wzrost 6,98\% rocznie), z którymi Chiny muszą dopiero zbudować odpowiednie relacje.

Ogromna skala planowanych inwestycji przyciąga w stronę Chin kraje nie będące pod silnymi wpływami USA, takie jak Kambodża, Bangladesz czy Pakistan. Jednocześnie Chiny działają w kierunku zatwierdzenia umowy o wolnym handlu pomiędzy 16 krajami. Państwa te odpowiadają za 30\% światowego PKB, czyli niemal dwa razy więcej niż cała Unia Europejska. 
Warto zaznaczyć, że odejście USA od globalizmu także poprzez wycofanie się z Partnerstwa Transpacyficznego (TPP) w czasie prezydentury Donalda Trumpa zwiększyło szanse Chin w szukaniu nowych partnerów gospodarczych. Ogromne środki przeznaczone na inwestycje oraz szerokie grono państw, które dołączyły do Azjatyckiego Banku Inwestycji Infrastrukturalnych (AIIB), sugerują, że Państwo Środka ma obecnie ogromne pole do działania.

\section{Gwadar Port - kluczowy punkt Nowego Jedwabnego Szlaku}

Spośród wszystkich elementów Nowego Jedwabnego Szlaku jedno miejsce wydaje się być wyjątkowo ważne - Gwadar Port w Pakistanie. Jego przebudowa (wraz ze stworzeniem sieci dróg, torów kolejowych itd.) ma skrócić czas importu ropy naftowej do Chin z 45 do zaledwie 10 dni. Wspomniane zmiany znacząco wzmocnią również pozycję Pakistanu, który nie tylko zyska przetransferowane przez Chińczyków środki finansowe, ale i będzie zarabiał na opłatach transportowych. Inwestycja w port przyspieszy zatem tempo rozwoju gospodarczego Pakistanu.

Można zakładać, że z czasem Gwadar stanie się dla Chin bazą podobną do tych, które na całym świecie tworzą Stany Zjednoczone, a liczba ludności w tym mieście (obecnie 100 tys. mieszkańców) wzrośnie kilkukrotnie. Krótsza trasa transportu ropy naftowej do Chin oznacza dla gospodarki Państwa Środka niższe koszty zakupu tego surowca. Jest to kolejny aspekt, który może zwiększyć zyski chińskich przedsiębiorstw.

Współpraca Pakistanu i Chin może sprawić, że po drugiej stronie barykady wspólnie znajdą się Stany Zjednoczone i Iran (jak również Japonia oraz Indie). Dotychczas Iran traktowany jest przez USA jak największe zło, niewykluczone jednak, że z czasem sytuacja ta ulegnie zmianie. Na dzień dzisiejszy trudno to sobie wyobrazić chociażby ze względu na sojusz USA z Arabią Saudyjską. Pamiętać jednak należy, że w polityce pewne zmiany zachodzą bardzo szybko.

\section{Kontrowersje wokół Nowego Jedwabnego Szlaku}

Nowy Jedwabny Szlak przyczyni się do zmiany 500-letniej globalnej struktury świata. W przeszłości wszystkie mocarstwa opierały swoją potęgę o handel morski. Chiny zamierzają dorzucić do tego drogę lądową, co pozwoli silnie rozwinąć zarówno Państwo Środka, jak i Rosję.

Nie nastąpi to oczywiście z dnia na dzień, co jakiś czas można jednak zauważyć symboliczne wydarzenia, które zapowiadają wielkie zmiany. Dobrym przykładem jest tu Wielka Brytania (sojusznik USA), która była jednym z pierwszych 
europejskich państw, jakie dołączyły do AIIB. Jednocześnie trzeba zaznaczyć, że realizacja Nowego Jedwabnego Szlaku może napotkać pewne trudności, a jego budowa może potrwać znacznie dłużej, niż mogło się początkowo wydawać.

Warto podkreślić, że projekt Nowego Jedwabnego Szlaku stworzył zupełnie nową sytuację, w której wpływy Chin zaczęły sięgać poza tradycyjną strefę. Odczuły już to nie tylko wspomniane wcześniej małe państwa, ale także Australia. W ostatnim okresie przez Antypody przetoczyło się kilka burz związanych z nadmiarem chińskich inwestycji i rosnącą zależnością od chińskiego kapitału. Pewne zakłopotanie pojawiło się, gdy na jaw wyszło wspieranie i finansowanie przez ChRL sprzyjających jej australijskich polityków. Kolejny skandal dotyczył infiltracji i prób wykorzystania do celów politycznych przez służby specjalne Państwa Środka chińskiej mniejszości. W tej sytuacji władze Australii zaczęły przybierać coraz bardziej antychiński kurs. Jednym z elementów polityki powstrzymywania Chin jest promowana przez administrację prezydenta USA Donalda Trumpa koncepcja Quadrilateral Security Dialogue (Quad), czyli luźnego sojuszu USA, Indii, Japonii i Australii. Zaznaczyć należy, że sama koncepcja tego, czym dokładnie ma być Quad, dopiero się krystalizuje. Wygląda na to, że Indie są zainteresowane bardzo ogólnym porozumieniem, podczas gdy reszta państw może dążyć do bardziej konkretnych rozwiązań. Niewykluczone również, że współpraca czterostronna przekształci się w sześciostronną. Zainteresowanie Quadem wykazują Francja i Wielka Brytania, mające jeszcze dość rozległe interesy w rejonie Indo-Pacyfiku.

Pojawia się również pytanie, do jakiego stopnia Chiny chcą kontrolować Nowy Jedwabny Szlak. Wykorzystanie Pasa i Szlaku w roli narzędzia politycznego będzie wymagać od władz chińskich jak najdalej posuniętej kontroli. Tymczasem wobec spodziewanych olbrzymich zysków zaczęły pojawiać się inne pomysły na Jedwabny Szlak. Propozycje uwzględniające przede wszystkim własne, a nie chińskie interesy zgłaszają już Rosja, Iran, Indie, Indonezja, ASEAN i Japonia. Najdalej poszły jednak Finlandia i Norwegia.

Topnienie lodów Arktyki powoduje w tym regionie powolny wzrost intensywności żeglugi, a tym samym znaczenia Północnej Drogi Morskiej. Główną zaletą szlaku arktycznego jest krótszy czas żeglugi z Azji Wschodniej do Europy Północnej i Zachodniej. Zwróciło to baczną uwagę Chin, które uwzględniły daleką północ w Inicjatywie Pasa i Szlaku, a w styczniu 2018 r. uznały się nawet za państwo położone blisko Arktyki. Chińskie zapędy mogą jednak spotkać się z poważną kontrakcją Rosji i państw skandynawskich, widzących dla siebie olbrzymią szansę w rozwoju żeglugi arktycznej. W marcu 2018 r. Finlandia i Norwegia zadecydowały o rozbudowie portu w Kirkenes i połączniu go linią kolejową z Rovaniemi. Tak zwany Korytarz Arktyczny będzie się tam łączyć z europejską siecią dróg i kolei. Warto również wskazać, że plany Skandynawów obejmują nie tylko Chiny, ale także Japonię, Koreę Południową i Tajwan. Najważniejszym zadaniem 
Chin na obecnym etapie jest przekopanie tunelu z Helsinek do Tallina, chociaż chińskie inwestycje w Kirkenes także będą mile widziane.

Nie oznacza to, że Chiny nie są zainteresowane Skandynawią. Pod koniec listopada 2017 r. holding Sunbase International mający siedzibę w Hongkongu zaproponował położonej w zachodniej Szwecji gminie Lysekil budowę największego portu w regionie wraz $\mathrm{z}$ infrastrukturą drogową i kolejową, w tym połączeniem mostem obu brzegów pobliskiego fiordu. Dodatkowy pakiet obejmował inwestycje w lokalne szkolnictwo i opiekę zdrowotną. Przyzwyczajenia wyniesione z krajów Azji i Afryki okazały się jednak przyczyną porażki. Sunbase otoczył ofertę tajemnicą, a kiedy sprawa ujrzała światło dzienne, żądał od władz, by podjęły decyzję w ciągu 10 dni. Sprawa wywołała burzę w szwedzkich mediach. Przeciwnicy chińskiej inwestycji wytaczali argumenty natury politycznej, gospodarczej i ekologicznej. Z czasem ujawniono, że prezes holdingu, Gunter Gao Jingde, jest silnie powiązany z KPCh i chińskimi siłami zbrojnymi, a także podejrzewany o udział w fałszowaniu wyników wyborów w Hongkongu. Ostrzegano przed możliwością wykorzystania portu przez chińską marynarkę wojenną, podobnie jak na Sri Lance. Wskazywano również na zbieżność geopolitycznych interesów Pekinu i Kremla, która stwarza zagrożenie dla linii komunikacyjnych państw skandynawskich na wypadek wojny z Rosją. Władze Lysekil pod naciskiem opinii publicznej wycofały się z rozmów pod koniec stycznia 2018 r.

Nie była to jedyna niewłaściwa decyzja chińskich inwestorów w Europie w ostatnim czasie. W lutym 2018 r. zatrzymano Ye Jianminga, prezesa CEFC, konglomeratu działającego w branżach energetycznej i finansowej. Finansowany przez państwowe banki Ye był największym chińskim inwestorem działającym w Czechach. Sprawa ta jest bardzo tajemnicza. Jako przyczynę aresztowania podano „podejrzenie pogwałcenia prawa”. Można dodać, że losem Ye zainteresowała się kancelaria prezydenta Milosza Zemana, która nic jednak nie wskórała. Według strony czeskiej, chiński państwowy holding CITIC Group przygotowuje się do przejęcia pakietu większościowego CEFC Europe, mniejsze pakiety akcji filii CEFC są natomiast przejmowane przez inne podmioty państwowe. Możliwe, że Ye zaczął grać zbyt samodzielnie i bardziej zwracał uwagę na swoje interesy niż na interesy ChRL. Jeżeli to przypuszczenie jest prawdziwe, obrazuje to stopień zależności zagranicznych projektów biznesowych od polityki.

Z konsekwencji realizacji Nowego Jedwabnego Szlaku coraz bardziej zaczynają sobie zdawać sprawę Niemcy. Z racji intensywnych i zażyłych kontaktów handlowych przez lata mówiono o chińsko-niemieckich relacjach specjalnych. Atmosfera zaczęła się jednak psuć w latach 2016-2017. W zamian za przyjmowanie inwestycji strona niemiecka zaczęła domagać się szerszego otwarcia rynku chińskiego. Dla Niemiec, podobnie jak dla większości państw, w tym także UE, kluczowe pozostaje zrównoważenie deficytu w handlu z Chinami. Pierwszy po- 
ważny zgrzyt miał miejsce w czerwcu 2016 r. podczas dziewiątej wizyty kanclerz Angeli Merkel w Chinach. W czasie wspólnej konferencji prasowej premier Li Keqiang uniemożliwił jej udzielenie odpowiedzi na pytanie dotyczące Morza Południowochińskiego. W listopadzie tego samego roku w Pekinie ówczesny minister gospodarki Sigmar Gabriel ku dużemu niezadowoleniu Chińczyków dał jasno do zrozumienia, że jego głównym zadaniem jest obrona interesów gospodarczych Niemiec. Nowe podejście do Chin określił później jako „mierzenie się z 400-kilogramowym gorylem". Również wśród niemieckich przedsiębiorców coraz bardziej zauważalne stają się jeśli nie obawy, to co najmniej sceptycyzm względem Chin. Przyczyną jest rosnące wykupywanie firm z branży zaawansowanych technologii. Sztandarowym przykładem jest producent robotów przemysłowych KUKA. Podjęte przez Berlin działania mające utrudnić takie przejęcia przyniosły pewne sukcesy, ale zaowocowały również wykupieniem „przez tylne drzwi" 10\% akcji Daimlera przez Geely. Chiński producent samochodów dokonał zakupu za pośrednictwem kilku fikcyjnych firm.

Kolejnym problemem jest dla Niemców rosnące zainteresowanie Chińczyków innymi branżami. Państwowa spółka SGCC jest zainteresowana zakupem $20 \%$ akcji dostawcy energii elektrycznej 50Hertz. Według nieoficjalnych doniesień kanclerz Merkel miała stwierdzić, że strategiczne interesy Chin w Europie stają się jednym z głównych problemów, z którymi trzeba się zmierzyć. W tej sytuacji nie dziwi początkowe zainteresowanie Berlina płynącymi z Waszyngtonu sugestiami zbudowania wspólnego frontu przeciw ChRL. Entuzjazm osłabł wraz z wysuniętą przez prezydenta Trumpa propozycją obłożenia cłami importu stali i aluminium, pomyślane jako wymierzone w Chiny cła mogą mieć bowiem gorsze konsekwencje dla sojuszników Stanów Zjednoczonych, w tym Niemiec. Chiny postanowily wykorzystać tę szansę. W rozmowie z kanclerz Merkel przewodniczący Xi Jinping wystąpił z sugestią niemiecko-chińskiego przewodnictwa w rozwoju relacji między Chinami i Europą, zwłaszcza w ramach Nowego Jedwabnego Szlaku. Xi miał również podkreślić znaczenie podtrzymywania wzajemnego zaufania [Behrendt, 2018].

\section{Nowy Jedwabny Szlak a Polska}

Pojawia się pytanie, jak w procesie realizacji Nowego Jedwabnego Szlaku wygląda sytuacja Polski. Niewątpliwym atutem jest jej położenie, zapewniające najłatwiejszy dostęp drogą lądową do Europy Zachodniej. Zważywszy jednak na proporcjonalnie małą skalę transportu lądowego oraz duże zainteresowanie Chin europejskimi portami konieczne jest większe zainteresowanie Morskim Jedwabnym Szlakiem. W tym kontekście najlepszym rozwiązaniem wydaje się zaangażo- 
wanie w tworzenie Korytarza Arktycznego. Trzeba przy tym pamiętać, że wielkie chińskie inwestycje zawsze mają polityczne konsekwencje. Kolejnym punktem budzącym niepokój jest wspomniana już zbieżność interesów geopolitycznych Rosji i Chin z punktu widzenia USA i szeroko pojętej dominacji świata zachodniego, a Azja Środkowa jawi się już jako obszar rywalizacji. W przyszłości podobnie będzie z Arktyką. Chiny są zainteresowane rozwojem i eksploatacją Północnej Drogi Morskiej, ale nie zgodzą się na zależność od Rosji.

Zważywszy na niski potencjał Polski dla Chin, konieczne będzie dołączenie do działań podejmowanych na szerszym froncie. Pierwszym krokiem będzie zatem decyzja w dyskutowanej kwestii „opcja niemiecka czy inna”. Ciekawy jest w tym kontekście casus Uzbekistanu. Środkowoazjatyckie państwo przyjęło rosnące zaangażowanie Chin w regionie z dużym zainteresowaniem, widząc w nim szansę na równoważenie wpływów Rosji i USA. Pytanie, jak długo uda się lawirować między trzema mocarstwami. Chiny już uzyskały w Azji Centralnej duże wpływy gospodarcze i - jak pokazuje doświadczenie - nie wahają się ich wykorzystywać.

Niewątpliwym atutem jest natomiast członkostwo w AIIB. Tworząc struktury alternatywne względem istniejących, Chińczycy stworzyli narzędzie umożliwiające innym państwom wgląd w inwestycje związane z Nowym Jedwabnym Szlakiem. Co więcej, inni członkowie mogą tworzyć grupy interesów i także za chińskie pieniądze realizować swoje plany, które niekoniecznie są po myśli władz chińskich [Behrendt, 2018].

Warto zaznaczyć, że w ramach inicjatywy podjęto już pierwsze działania inwestycyjne. Łódź była pierwszym miastem Europy Środkowej, do którego zaczęly kursować regularne pociągi kontenerowe z i do Chin. Połączenie ruszyło w kwietniu 2013 r. Pociągi z kontenerami kursują co najmniej raz w tygodniu i liczącą prawie 10 tys. $\mathrm{km}$ trasę pokonują w 12 do $14 \mathrm{dni}$. Obecnie w znacznej mierze wykorzystuje się je także do eksportu polskiej żywności: jabłek, piwa, soków, wody mineralnej, wyrobów cukierniczych i mleczarskich. Generalnie Polska eksportuje do Chin około 1\% swoich towarów, a wartość importu jest piętnastokrotnie wyższa.

Prowadzi się także działania mające na celu poznawanie w praktyce specyfiki kontaktów z chińskimi handlowcami i inwestorami oraz udział w zaaranżowanych aktywnościach biznesowych z wyselekcjonowanymi dużymi kupcami. W Polsce coraz więcej osób nawiązuje kontakty handlowe z Chinami, czemu sprzyjają bardzo duże polsko-chińskie targi handlowe.

Ocenia się, że przełamanie barier kulturowych nie powinno zająć obu stronom dużo czasu i stanowić utrudnienia dla międzynarodowego handlu. Problemem mogą się natomiast okazać różnice w prawodawstwie pomiędzy Chinami a Polską i Unią Europejską. Nie jest to rzecz łatwa, ponieważ trzeba także poznać odmienną chińską kulturę. Chińczycy pod tym względem mocno się rozwinęli 
i bez wątpienia lepiej znają już kulturę Europy Zachodniej. Głównym problemem jest zrozumienie polskiego prawodawstwa. Dzięki zharmonizowanym przepisom i przynależności do Unii Europejskiej Polacy mogą być pośrednikami i przewodnikami dla Chińczyków nie tylko w Polsce, lecz także w całej UE. Polacy są bardzo elastyczni i mogą sprawnie wprowadzić Chińczyków na teren Europy. Dużo zależy jednak od rządzących.

Premier Mateusz Morawiecki przychylnie odnosi się do możliwości rozbudowy Nowego Szlaku Jedwabnego. Należy podkreślić, że w czasie Chińsko-Polskiego Forum Inwestycji i Infrastruktury Logistycznej Pasa i Szlaku w połowie 2017 r. obecny premier Mateusz Morawiecki jako minister rozwoju pozytywnie wypowiadał się o tej inicjatywie. Stwierdził między innymi, że jest to ogromna szansa dla Polski i chińskich firm oraz że ważne jest, aby razem kształtować rzeczywistość gospodarczą między tymi krajami. Obecny na forum przewodniczący Ogólnochińskiego Zgromadzenia Przedstawicieli Ludowych Zhang Dejiang podkreślił natomiast, że Polska jest "aktywnym uczestnikiem budowy Pasa i Szlaku”.

Mimo to udział Polski w chińskim projekcie Nowego Jedwabnego Szlaku może być zagrożony, Niemcy i Rosja są bowiem zainteresowane przekierowaniem szlaku tak, aby omijał Polskę, i stworzeniem „kolejowego Nord Stream 2" [Moll, 2018]. Warto zaznaczyć, że operator rosyjskiej sieci kolejowej Rossijskije Żeleznyje Darogi (RŻD) oraz niemiecka firma Deutsche Bahn (DB) Cargo planują przekierować dostawy do portów w Kaliningradzie i Petersburgu, a następnie przesyłać ładunek przez Morze Bałtyckie do portów w Niemczech. Jest to spowodowane między innymi tym, że polska infrastruktura kolejowa mimo modernizacji wciąż nie jest w najlepszym stanie i może powodować opóźnienia w transporcie [Moll, 2018].

Dla Polski jest to zły znak, ponieważ pomysły polskich sąsiadów ostatecznie mogą odebrać Polsce nowe możliwości oraz zyski wynikające z udziału w chińskim projekcie i doprowadzić do dalszej izolacji w Europie i na świecie. Z drugiej strony Chiny nastawione są na współpracę z wieloma państwami, a Polskę traktują jako ważnego partnera w swoim wielkim przedsięwzięciu. Udział Polski w Nowym Jedwabnym Szlaku wciąż nie jest jednak pewny, ponieważ oficjalnie Polska jest sojusznikiem Stanów Zjednoczonych, które zwalczają chińską ekspansję na świecie i planują nawet utworzyć swój własny szlak [Moll, 2018].

\section{Powrót systemu trybutarnego?}

Takie postawienie problemu prowadzi do kwestii Węgier, głównego odbiorcy chińskich inwestycji w Europie Środkowej. Dobre relacje z chińskim biznesem zostały nawiązane w latach 90., a premier Węgier Victor Orbán kreuje się na głównego 
sojusznika Chin w regionie. Jest to o tyle ciekawe, że władze chińskie przyjmują te awanse z umiarkowanym entuzjazmem i przez lata głównego partnera w naszej części Europy upatrywały w Warszawie. Węgierski premier stara się przedstawić zacieśnienie związków z Chinami jako alternatywę wobec Europy Zachodniej. Sam jednak przyznaje, że interesy i plany jego oraz Pekinu wcale nie muszą być zbieżne.

Patrząc z szerszej perspektywy, należy ponownie przywołać dawny chiński system trybutarny. Jedną z jego cech było dopuszczanie na rynek chiński kupców z państw, które uznały zwierzchność Chin. Można więc założyć, że w hipotetycznej przyszłości Pekin zacznie używać dostępu do chińskiego rynku jako nagrody dla państw akceptujących jego zwierzchność. Trzeba tutaj mieć na uwadze, że cała idea Nowego Jedwabnego Szlaku ma służyć „pokojowemu wyjściu Chin w świat" i otwieraniu nowych rynków dla chińskiej gospodarki, opartej wszak na eksporcie. Dopuszczenie innych do chińskiego rynku wewnętrznego niekoniecznie mieści się $\mathrm{w}$ tym planie.

Ciągle niejasne jest, czy i w jakiej formie Chiny chcą odtworzyć system trybutarny, chociaż temat jest dyskutowany od lat 90 . W owym czasie głównym celem chińskiej strategii było jeszcze dogonienie Zachodu na polu naukowym, militarnym i gospodarczym. Pod wieloma względami już się to udało, a wraz z sukcesami wzrosła chińska pewność siebie i ambicje.

Przełożyło się to na jaśniejsze artykułowanie celów i bardziej asertywną politykę. Takie podejście wymaga jednak położenia większego nacisku na hard power kosztem promowanego dotychczas soft power. Twarde podejście najbardziej widoczne jest na Morzu Południowochińskim, gdzie polityka faktów dokonanych, presja ekonomiczna i budowa sztucznych wysp w ciągu zaledwie 5 lat drastycznie zmieniły sytuację na korzyść Chin. Podobne trendy zaczynają być widoczne wzdłuż Nowego Jedwabnego Szlaku. Rodzi to uzasadnione obawy o cele przyświecające Chinom - państwa nie zostają wszak wielkimi mocarstwami z pobudek humanitarnych i dobroczynnych, tylko dla własnej korzyści [Moll, 2018].

\section{Ocena Nowego Jedwabnego Szlaku}

Inicjatywę „Pasa i Szlaku” ocenia się bardzo różnie - z jednej strony dostrzega się szanse rozwojowe, które tworzy powstanie niezbędnej infrastruktury na zapóźnionych obszarach, z drugiej pojawiają się obawy przed rosnącymi wpływami Pekinu. Pikanterii dodaje fakt, że wciąż nie ma zgody co do kształtu wizji zarysowanej w 2013 r. przez przewodniczącego Xi Jinpinga, a jej realizacja jest zaplanowana na kilkadziesiąt lat. Nie wiadomo nawet, jaki właściwie obszar obejmuje i będzie obejmował „Pas i Szlak”. Chińczycy regularnie aktualizują koncepcję, 
włączając do niej już nie tylko Azję i Pacyfik, Afrykę oraz Europę, ale również Amerykę Południową czy Arktykę, czyli właściwie cały świat, oprócz dotychczasowych potęg niechętnych Pekinowi: światowej - USA oraz regionalnej - Japonii. Do tego grona niedawno dołączyły Indie.

Obecnie uwaga obserwatorów koncentruje się na rozbudowie infrastruktury drogowej, kolejowej, energetycznej czy morskiej - ale na gospodarczym horyzoncie pojawiają się również ułatwienia w handlu i inwestycjach, które będą oznaczać szersze otwarcie na ekspansję firm zza Muru. Kraje rozwinięte nie narzekają ani na brak dostępu do kredytu, ani na poważne niedostatki infrastrukturalne, dlatego oferta Pekinu nie jest dla nich atrakcyjna. Warto zaznaczyć, że dopóki Chińczycy nie zgodzą się na poprawę dostępu do swojego rynku i równe traktowanie firm zagranicznych, brak równowagi we wzajemnych relacjach gospodarczych będzie napędzał niechęć do Państwa Środka, i tak silną wskutek odmiennego systemu politycznego czy kulturowego.

Należy podkreślić, że dla państw rozwijających się bardzo ważną kwestią jest poprawa infrastruktury. Dla nich chińska oferta budowy autostrad, linii kolejowych, sieci energetycznych czy portów morskich za środki pożyczone przez Pekin jest szansą na rozwój. Nie podoba im się za to inna chińska praktyka, a mianowicie udzielanie kredytu gwarantowanego przez państwo-gospodarza na projekt infrastrukturalny, który jest realizowany przez chińskie firmy zatrudniające chińskich pracowników, przynajmniej tych wyższego szczebla.

\subsection{Rozwój infrastruktury}

Infrastruktura ma mnóstwo zalet. Przede wszystkim poprawia warunki prowadzenia działalności gospodarczej, zapewnia lepszy dostęp do dóbr i usług dla konsumentów, powoduje wzrost atrakcyjności inwestycyjnej obszaru, ułatwia prowadzenie handlu zagranicznego czy wspiera mobilność siły roboczej. Nie można też zapominać o ogólnej poprawie warunków życia.

Niestety, koszty jej budowy i utrzymania często przekraczają dochody, jakie przynosi ona do budżetu. Państwo musi się zatem liczyć z tym, że do części projektów będzie musiało regularnie dopłacać. Dlatego projekty infrastrukturalne nierzadko budzą kontrowersje, szczególnie gdy są drogie i budowane na kredyt. Dług trzeba spłacać, przez co często brakuje środków na inne cele. Wtedy pojawia się pytanie, czy ograniczyć pozostałe wydatki, czy zwiększyć podatki. Żadna z tych możliwości nie spotyka się raczej z entuzjazmem społeczeństwa. Jeżeli dług nie jest spłacany, a kredytodawcą jest zagraniczna potęga, pojawiają się kwestie koncesji politycznych i gospodarczych ograniczających suwerenność kredytobiorcy. 


\subsection{Kraje mogące wpaść w pułapkę zadłużenia}

Interesujące jest dokonanie sprawdzenia, które z 68 krajów leżących na „Pasie i Szlaku" są szczególnie zagrożone wpadnięciem w pułapkę zadłużenia. Na początku odrzucono 35 państw posiadających rating inwestycyjny w jednej z głównych agencji (na tym etapie odpadła m.in. Polska), a także 8 posiadających bardzo niski poziom długu publicznego i pozytywną ocenę MFW lub Banku Światowego oraz Syrię i Jemen, które nie będą w najbliższym czasie aktywnymi uczestnikami „Pasa i Szlaku” ze względu na wojny toczące się na ich terenie.

Pozostałe 23 państwa zostały poddane badaniom pod kątem obecnego poziomu długu publicznego oraz zobowiązań wobec Chin. Następnie eksperci dokonali obliczeń, jak zwiększą się te wartości, jeżeli dojdzie do realizacji ogłoszonych już, a nieuwzględnionych w powyższych danych projektów w ramach inicjatywy „Pasa i Szlaku”. Efektem było wyselekcjonowanie ośmiu krajów - Laosu, Dżibuti, Czarnogóry, Malediwów, Pakistanu, Mongolii, Tadżykistanu i Kirgistanu - które są szczególnie narażone na wpadnięcie w chińską pułapkę zadłużenia.

W Dżibuti za kredyt z Pekinu powstaną dwa lotniska, port, terminal naftowy i droga. Na Malediwach będzie rozbudowywana infrastruktura turystyczna, w tym lotnisko. W Laosie za chińskie pieniądze zostanie stworzona linia kolejowa łącząca kraj z Państwem Środka. Czarnogóra zamierza zbudować infrastrukturę drogową poprawiającą łączność z innymi państwami bałkańskimi. Mongolia stawia elektrownię wodną i autostradę, a Tadżykistan i Kirgistan, obok podobnych projektów, także gazociąg.

W efekcie w tych krajach dług publiczny przekroczy lub zbliży się do $60 \%$ $\mathrm{PKB}$, a równocześnie udział Chin w długu zagranicznym przekroczy $40 \%$. Należy zaznaczyć, że ta analiza ma pewne wady - przede wszystkim nie wiadomo, jakie naprawdę są koszty zaplanowanych projektów, ani czy będą one w ogóle realizowane. Chińczycy nie są specjalnie przywiązani do idei transparentności. Poza tym nikt nie wie, jakie będą kolejne inwestycje i ile będą kosztować - pułapka zadłużenia będzie zatem czekać i na pozostałe kraje. Nie jest też pewne, jakie będzie tempo wzrostu gospodarczego, kurs dolara (w którym kredyty są zazwyczaj udzielane) czy juana (w którym coraz częściej będą), stopy procentowe (które są obecnie na historycznie niskich poziomach, a zależy od nich wysokość rat) i inflacja (od której zależą wpływy budżetowe na pokrycie długu). Nie jest też wcale powiedziane, że uczestnicy „Pasa i Szlaku” nie będą zaciągać innych pożyczek, niekoniecznie za Murem. Każda z nich może przy tym doprowadzić do problemów, szczególnie gdy powrócą zagadnienia w wysoce zadłużonej gospodarce globalnej.

W rezultacie sukces lub porażka będą zależeć od polityki prowadzonej przez poszczególne państwa. Pojawia się także pytanie, czy Chiny będą realizować nieracjonalne projekty infrastrukturalne. Czy potrafią wykorzystać nową infrastruk- 
turę do usprawnienia gospodarki? Czy zaakceptują niekorzystne warunki kredytowania inwestycji?

\section{3. „Pas i Szlak” a możliwości kryzysu zadłużenia na świecie}

Przedstawia się również pozytywny obraz, wskazując, że „Pas i Szlak” raczej nie spowoduje kryzysu zadłużenia w regionie, choć może dotknąć pojedynczych członków. Podaje się również ponad 80 przykładów sytuacji, gdy Pekin odpuścił borykającym się z problemami gospodarczymi dłużnikom. Nie wiadomo jednak, co otrzymał w zamian za poświęcone pieniądze. Głośne są jednak dwa przykłady Sri Lanki, która oddała port w 99-letnią dzierżawę chińskim firmom, i Tadżykistanu, który przekazał Chińczykom część spornych terytoriów. Są to najbardziej drastyczne przykłady, a zazwyczaj ustępstwa są dużo mniej kosztowne i ograniczają się do poparcia Chin w kwestiach politycznych na arenie międzynarodowej czy zwiększenia wymiany handlowej (zazwyczaj importu).

Fakt, że Pekin niczego nie daje za darmo, jest bezsprzeczny, ale twierdzenie, że inicjatywa "Pasa i Szlaku” jest realizowana tylko po to, by wpędzić kilka krajów w kredytową pułapkę, jest grubym nadużyciem. Chiny są w stanie znaleźć dużo mniej kosztowne i prostsze sposoby, by zyskać przychylność rządzących kilkoma małymi i biednymi państwami, co zresztą dzieje się od dobrych kilku lat. „Pas i Szlak" to przede wszystkim pokaz globalnych ambicji Pekinu pod rządami najsilniejszego lidera od czasów Mao Zedonga - Xi Jinpinga - oraz nieuchronny etap rozwoju gospodarczego i próba wyrównania ogromnych nierówności między zachodem i północą a południem i wschodem Państwa Środka [Kalwasiński, 2018].

\subsection{Opozycja państw Zachodu wobec „Nowego Jedwabnego Szlaku”}

Wewnątrz społeczności międzynarodowej formuje się coraz większy opór wobec chińskich planów rewitalizacji dawnego szlaku jedwabnego. Stany Zjednoczone, Australia, Indie i Japonia rozważają alternatywę dla tej gigantycznej inwestycji mającej wspierać handel Chińskiej Republiki Ludowej. Rozmowy w sprawie alternatyw dla "Nowego Jedwabnego Szlaku” są jeszcze we wstępnej fazie realizacji, nie ma więc co liczyć na jakiekolwiek konkretne ustalenia w czasie obecnych kontaktów i rozmów o charakterze politycznym.

W Unii Europejskiej, m.in. w Niemczech, intensywnie rozmyśla się nad reakcją na chińskie plany inwestycyjne. „Nowy Jedwabny Szlak” nie jest, jak sądzą niektórzy w Niemczech, sentymentalnym wspomnieniem. Jest to próba stworzenia ogromnego systemu, za pomocą którego Chińczycy chcą wycisnąć swoje piętno w świecie, jak ostrzegał niemiecki minister spraw zagranicznych Sigmar Gabriel na Monachijskiej Konferencji Bezpieczeństwa na początku 2018 r. 
W umowie koalicyjnej nowego niemieckiego rządu zawartej przez chadeków i socjaldemokratów zapisano m.in. wolę sformułowania europejskiej odpowiedzi na „Nowy Jedwabny Szlak”. Szef francuskiego rządu Edouard Philippe również na Monachijskiej Konferencji Bezpieczeństwa ostrzegał, że Europa nie może pozostawić tego gigantycznego projektu wyłącznie w rękach Chin. Podkreślit, że w zależności od tego, jakie reguły będą obowiązywać w tym projekcie, będzie to albo współpraca, albo hegemonia.

Na początku lutego 2018 r. premier Wielkiej Brytanii Theresa May nie podpisała listu intencyjnego w sprawie „Nowego Jedwabnego Szlaku”. Szefowa brytyjskiego rządu wspomniała o możliwościach, jakie niesie za sobą inicjatywa, ale dodała przy tym, że Chiny i Wielka Brytania będą wspólnie pracować nad tym, aby inicjatywa "spełniała międzynarodowe standardy".

Warto zaznaczyć, że Szlak Jedwabny od czasów starożytnych do wczesnego średniowiecza był głównym szlakiem handlowym łączącym Chiny z Europą i Bliskim Wschodem. Chiny zapowiedziały w 2013 r. rewitalizację tego szlaku dla intensywnego wsparcia swojej gospodarki. Zamierzają one przeznaczyć ok. 113 mld EUR na infrastrukturę nowych tras handlowych do Europy, Azji i Afryki.

Krytycy obawiają się, że Chiny będą chciały w ten sposób rozszerzyć przede wszystkim swój wpływ na gospodarkę światową. Podkreśla się, że nikt nie chce Chinom zabronić budowy infrastruktury, lecz chodzi raczej o współpracę, która zapewniłaby ekonomiczny sukces wszystkim stronom. Z tego względu plany Australii, Stanów Zjednoczonych, Indii i Japonii należy postrzegać raczej jako alternatywę niż jako konkurencję dla szlaku jedwabnego.

\section{Podsumowanie}

Należy podkreślić, że Chiny nastawione są na współpracę z wieloma państwami. W Unii Europejskiej, m.in. w Niemczech, intensywnie rozmyśla się równocześnie nad reakcją na chińskie plany inwestycyjne. Zauważa się także, iż „Nowy Jedwabny Szlak” nie jest, jak sądzą niektórzy w Niemczech, sentymentalnym wspomnieniem. Podkreśla się, że jest to próba stworzenia ogromnego systemu, za pomocą którego Chińczycy chcą wycisnąć swoje piętno w świecie. Państwa Unii Europejskiej obawiają się, że celem tego nowego projektu jest przede wszystkim rozszerzenie oddziaływania Chin na gospodarkę światową z uwzględnieniem własnych interesów. Wskazuje się, że w zależności od tego, jakie reguły będą obowiązywać w tym projekcie, będzie to albo współpraca, albo hegemonia. 


\section{Źródła finansowania}

Artykuł przygotowano w ramach grantu OPUS, Narodowe Centrum Nauki, nr UMO 2013/11/B/HS5/03572.

\section{Bibliografia}

Behrendt P., 2018, Nowy Jedwabny Szlak - projekt polityczny, Nowa Konfederacja, https:// nowakonfederacja.pl/nowy-jedwabny-szlak-projekt-polityczny/ [dostęp: 22.05.2018].

Independent Trader, 2017, Jak Nowy Jedwabny Szlak zmieni świat?, https://independenttrader.pl/jak-nowy-jedwabny-szlak-zmieni-swiat.html [dostęp: 22.05.2018].

Kalwasiński M., 2018, "Pas i Szlak” - chińska pułapka kredytowa?, Bankier.pl, https://www. bankier.pl/wiadomosc/Pas-i-Szlak-chinska-pulapka-kredytowa-Analiza-7576219.html [dostęp: 22.05.2018].

Onet, 2018, Zachód w opozycji do projektu wspieranego przez Polskę, https://wiadomosci. onet.pl/swiat/zachod-w-opozycji-do-projektu-wspieranego-przez-polske/m3qryfw [dostęp: 22.05.2018].

Moll J., 2018, Nowy Jedwabny Szlak nie dla Polski? Rosja i Niemcy chca zbudować "kolejowy Nord Stream 2", zmianynaziemi.pl, https://zmianynaziemi.pl/wiadomosc/nowy-jedwabnyszlak-nie-dla-polski-rosja-i-niemcy-chca-zbudowac-kolejowy-nord-stream-2 [dostęp: 22.05.2018].

Z.W. Puślecki (®) zdzislaw.puslecki@amu.edu.pl

Zakład Gospodarki Międzynarodowej, Wydział Nauk Politycznych i Dziennikarstwa, Uniwersytet im. Adama Mickiewicza w Poznaniu, ul. Uniwersytetu Poznańskiego 5, 61-614 Poznań, Polska 